\title{
An Investigation Of The Effect Of Methods Of Recording Accounting Principle Changes On The Decisions Of Users In The United States, Germany, And Austria
}

Linda M. Nichols, (Email: Linda.Nichols@ttu.edu), Texas Tech University

Kurt H. Buerger, (Email: Kurt.Buerger@angelo.edu), Angelo State University

\begin{abstract}
Formerly in the United States, most accounting principle changes were traditionally recorded using the cumulative effect method, wherein the net effect of the principle change flows through the income statement as a special item. International accounting standards, in comparison, have recorded accounting principle changes retrospectively by adjusting beginning stockholders' equity in the year of the change. In 2002, the FASB began a convergence project with the IASB, in which they have and are attempting to agree on standard accounting treatments in areas in which the U.S. standards and IAS differ. The project initially looked at seventeen areas of difference in which it was believed that convergence could be reached. One of those areas was in accounting for principle changes. Resulting from the convergence project, the FASB issued SFAS No. 154 in 2005, which changes U.S. GAAP to require that accounting principle changes be recorded retrospectively, as is required by international standards. This study examines the decisions of statement users in the U.S., Germany, and Austria to determine if the method of accounting used for principle changes affects their decisions. The findings reveal that the method used in interaction with the home country of the user has a significant effect on the decisions of statement users.
\end{abstract}

\section{INTRODUCTION}

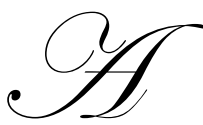

s we move closer to having a truly global market for capital, the need and desire for accepted international accounting standards is becoming more pressing. The International Accounting Standards Board (IASB) has made significant progress toward the development of a complete and comprehensive set of international accounting standards. Many countries already endorse the IASB standards as their own, either without amendment or with minor additions or deletions. In 2001, the European Commission announced the requirement that all listed companies in the European Union (EU) publish consolidated statements in accordance with IASB standards beginning in 2005. The EU's decision to require consolidated statements in accordance with IASB standards is greatly enhancing the acceptance of IASB standards on a worldwide basis.

The United States (U.S.), however, has not yet fully endorsed IASB standards. While the Securities and Exchange Commission (SEC) has voiced support of the IASB, the U.S. has continued to maintain its own generally accepted accounting principles (GAAP), issued currently by the Financial Accounting Standards Board (FASB). The need for convergence between U.S. standards and international standards has, however, been recognized. In 2002, the FASB joined in a convergence project with the IASB, in which they are attempting to agree on accounting treatments in areas in which U.S. standards and international accounting standards currently differ. The project initially looked at seventeen areas of difference in which it was believed that convergence could be reached. One of those areas was in the recording of accounting principle changes. 
Prior to the convergence project, most accounting principle changes in the United States were recorded using the cumulative-effect method, wherein the effect of the principle change, net of tax, flows through the income statement as a special item. International accounting standards, in comparison, record accounting principle changes retrospectively by adjusting beginning stockholders' equity of the earliest period for which financial statements are presented for comparative purposes. Does the method of recording accounting principle changes make a difference to financial statement users? This study examines the behavioral effects on U.S., German and Austrian decision makers of differing methods of recording accounting principle changes. The results of the study provide insight into how reporting methods influence the decisions of statement users in countries with different accounting traditions. The remainder of this paper consists of background on the convergence project, discussion of the reporting of principle changes, prior research, research design, response analysis, and conclusions.

\section{THE CONVERGENCE PROJECT}

In September 2002, The FASB and the IASB agreed to undertake a short-term convergence project to reduce differences between International Accounting Standards (IAS) and U.S. GAAP. The issues considered in this project were those thought to be capable of resolution in the short term.

There were three components of the convergence project:

- $\quad$ Reduction of differences arising from proposals in the IASB improvements project. These differences include: classification of liabilities on breach of borrowing agreement, asset exchanges, voluntary changes in accounting principles and policies, financial instruments, and transitional requirements.

- Reduction of differences arising from recent FASB statements. These differences include discontinued activities, accounting for costs associated with exit or disposal activities, and government grants.

- Reduction of other differences. These differences include inventories, changes in accounting estimates and errors, depreciation on assets held for disposal, income taxes, construction contracts, hyperinflationary economies, joint ventures, interim financial reporting, and research and development.

The Boards agreed to use their best efforts toward issuing statements of proposed changes for some, if not all, of the identified differences. Differences which are not a part of the short-term project, will be addressed over a longer term as the FASB and the IASB coordinate their future agendas. In addition, the FASB has stated that, within the framework of their agenda criteria, they will assess all agenda items for the possibility of cooperation with the IASB.

Substantial progress has been made on the convergence project since it was undertaken in 2002. Both the FASB and the IASB have made concerted efforts to converge their prescribed practices where possible. The FASB has issued several standards aimed at convergence, including a revision of SFAS No. 123 concerning share-based compensation, SFAS No. 151 on inventory cost dealing with idle facility expense and spoilage, and SFAS No. 153 dealing with nonmonetary exchanges. Most relevant to this study, however, is the issuance of SFAS No. 154 on accounting changes and error corrections. The statement requires retrospective application to prior periods' financial statements of changes in accounting principle, unless it is impracticable to do so. Thus, U.S. GAAP is changing to converge with international standards in the reporting of principle changes. The IASB has also issued new standards and amendments to existing standards with the purpose of convergence since the project began. Areas addressed by the IASB's new standards include discontinued operations, construction contracts, income taxes, contingencies, and government grants. In July of 2005, the IASB and the FASB announced their first major Exposure Draft produced jointly. The Draft contains proposals to improve and align the accounting for business combinations.

\section{METHODS OF REPORTING PRINCIPLE CHANGES}

Accounting principle changes involve a change from one generally accepted accounting principle to another generally accepted accounting principle. An example would be a change from the straight-line method of depreciating plant assets to the double-declining-balance method. Adoption of a new principle due to events that have occurred for the first time or that were previously immaterial are not considered principle changes. Also, if a principle which had 
been previously followed was not acceptable, or if an accepted principle had been applied incorrectly, then the change to a generally accepted accounting principle properly applied is considered to be a correction of an error rather than a principle change.

In the U.S., SFAS No. 154 will require retrospective application of principle changes, and will be effective for fiscal years beginning after December 15, 2005. Until that Statement takes effect, accounting for principle changes is addressed in APB Opinion No. 20. Traditionally in the U.S., under APB No. 20, most accounting principle changes have been recorded using the cumulative-effect method. Under that method, the cumulative effect of the adjustment for prior periods, net of tax, is recorded as a special item on the bottom of the income statement, following extraordinary items. Prior period financial statements reported for comparative purposes are not restated. Income before extraordinary items and net income, computed on a pro forma (as if) basis is disclosed for all periods presented. The pro forma figures are computed as if the newly adopted principle had been applied during all periods presented. In limited circumstances, principle changes are reported using retroactive restatement in which the statements of prior periods are recast to be consistent with the newly adopted accounting principle. In that case, the cumulative effect of the change attributable to years prior to those presented is adjusted to beginning retained earnings of the earliest year presented. Under APB No. 20, only the five following situations require retroactive restatement:

- $\quad$ A change from LIFO inventory valuation to another method.

- A change in the method of accounting for long-term construction contracts.

- $\quad$ A change to or from the full-cost method of accounting in the extractive industries.

- Issuance of statements for the first time to obtain additional equity capital, to effect a business combination, or to register securities.

- A professional pronouncement recommends that a change in principle be treated retroactively.

A final exception under traditional U.S. GAAP involves a change made to adopt the LIFO method of inventory valuation. In that case, no cumulative effect is computed because it would be impractical to do so. Any computation of a cumulative effect would be subject to assumptions regarding when LIFO layers had been previously established, which can be very difficult to substantiate. Instead, the beginning inventory for the year in which LIFO is adopted is used as the base-year inventory for all subsequent LIFO calculations.

In December 2003, the International Accounting Standards Board issued IAS 8 concerning changes in accounting policies, errors, and estimates. The standard is applicable for annual periods beginning on or after January 1,2005 . That standard requires accounting principle changes to be applied retrospectively to all periods presented in the financial statements as if the new accounting policy had always been applied. For principle changes resulting from the issuance of a new standard or interpretation, the change is accounted for in accordance with any specific transitional provisions of the new pronouncement. The IASB does not allow the cumulative-effect method to be used in recording accounting principle changes. They believe that a principle change should not be recorded as a incomegenerating (or losing) activity, and should not flow through the income statement.

\section{PRIOR RESEARCH}

Prior studies, including a study by Finger (1994), have found a significant relationship between reported earnings and future earnings and cash flows. Prior research has also shown the relevance of reporting separate earnings components by examining the market reaction to components of earnings. Gonedes (1975) found that returns are associated with the sign of unusual earnings components. Strong and Walker (1993) found that separating earnings into ordinary and unusual components increases the association between returns and earnings. Fairfield et al. (1996) found that disaggregation on the income statement improves the predictive content of earnings. The results of these studies imply that special components of income, including the cumulative effect of principle changes, are considered by statement users and reflected in market valuations.

Bouwman et al. (1995) used a behavioral setting to assess the relevance of financial reporting by observing financial analysts. They found that income statement information ranked at or near the top with every analysis activity. Nichols (1999) performed a behavioral study to assess the effect of the method of comprehensive income 
reporting on statement users. The results of her study revealed that users are better able to evaluate comprehensive earnings when they are reported in a separate statement of comprehensive income. Earlier survey studies also found that income statement information is used extensively by decision makers (Chandra, 1974; Porcano, 1981; Chang et al., 1983). Because income statement information is so important to users, it follows that users could be influenced differently when the effect of principle changes flow through the income statement instead of being recorded retroactively as a retained earnings adjustment.

Other prior research has also examined factors which affect lending decisions. For example, Nichols (1997) looked at the effect of reporting changes proposed by the AICPA in their "Model of Business Reporting" (1994), on decisions made by loan officers. The results revealed that the proposed separation of financial statement information into core and non-core activities as well as expanded segment information increased the decision usefulness of statements. Harper et al. (1987) found that pension information is not incorporated into the lending decision as often when it is provided in the form of supplemental disclosure as opposed to being included in the body of the financial statements. Similar findings were found regarding the disclosure or inclusion in the body of the statements of other postretirement benefit obligations (Harper et al. 1991). Danos et al. (1989) found that bankers utilize general background information and forward-looking data in making lending decisions. They also found evidence that the level of confidence which bankers place in their decisions increases as the amount of information they receive is increased. These studies provide evidence that both reporting methods and the level of disclosure affect the decisions of lenders.

\section{RESEARCH DESIGN}

This study addresses the question of whether the method used to record accounting principles changes affects the decisions of statement users. A behavioral approach to answering this question is taken, using bank loan officers to represent statement users.

The research instrument consists of a complete set of annual financial statements for a fictitious candy company. Included is an income statement, balance sheet, statement of cash flows, and retained earnings statement. Notes to the financial statements are included, along with a description of the company with a "clean" audit opinion. The instrument was mailed to bank loan officers in the U.S., Germany and Austria who were asked to make a lending decision for the company. The instruments mailed to Germany and Austria were converted to German with the currency converted to Euros using the rate in effect at the time of the mailing. The U.S. bankers were told that the company was U.S. based with foreign operations, while the German and Austrian bankers were told that the company was based in Germany with foreign operations.

\section{The Variables}

The research design is a $2 \times 2 \times 2$ factorial. The three factors are (1) the reporting method used, (2) the direction of the principle change, and (3) the accounting tradition.

The reporting method variable has two levels, the cumulative effect method of reporting an accounting principle change, and the retrospective method (retroactive restatement) of recording a change. The statements mailed to the bankers reflected a change in the method of inventory valuation. On the statements using the cumulative effect method, the net of tax cumulative effect of the change was reflected on the income statement as a special item. On the statements using the retrospective method, the same net of tax effect of the change was adjusted to beginning retained earnings in the U.S., and beginning stockholders' reserves in Germany and Austria. Under both methods, disclosure was included in the notes to the financial statements concerning the change and its effect.

The direction of the change variable also has two levels. The first level is a inventory valuation method change from first-in first-out (FIFO) to the average cost method, and the second level is a change from the average cost method to FIFO. Half of the statements sent out reflected a principle change in inventory valuation method from FIFO to the average cost method. On these statements, the effect of the change using the cumulative effect method was a decrease to income from operations of 15.3 percent. When using the retrospective method, the same amount 
reduced beginning retained earnings or reserves, reflecting a decrease to beginning retained earnings or reserves of 3.4 percent. The other half of the statements reflected a principle change in inventory valuation method from average cost to FIFO. This change resulted in an increase to income from operations of 15.3 percent when using the cumulative effect method. Beginning retained earnings or reserves increased by the same amount on statements using the retroactive restatement method, resulting in a 3.4 percent increase in retained earnings or reserves.

The accounting tradition variable has two levels. The first level is an Anglo-American tradition and is associated with the participants in the U.S., while the second level is a Germanic tradition which is associated with the participants in Germany and Austria.

Two dependent variables are used in this study. All subjects were asked to state the maximum amount they would be willing to lend the company on a five-year loan and the interest rate, stated as an amount above prime that they would charge. They were told to assume a prime rate of 4.5 percent and that their bank had an unlimited amount of funds with which to make loans.

\section{The Banker Subjects}

The research instruments were mailed to 400 bank loan officers from across the U.S., and 400 bank loan officers in total from across Germany and Austria. The names were obtained from the Thomson Global Banking Resource database. Each banker received one of four full sets of financial statements for the fictitious candy company. One set of financial statements reflected a change in inventory valuation from FIFO to average cost utilizing the cumulative effect method. The second set of financial statements reflected a change in inventory valuation from FIFO to average cost utilizing the retrospective method. The third set of financial statements reflected a change in inventory valuation from average cost to FIFO utilizing the cumulative effect method. The final set of financial statements reflected a change in inventory valuation from average cost to FIFO utilizing the retrospectiive method. The determination of which set of statements was received by the individual subjects was by random assignment. Banks with less than $\$ 75$ million in assets (or the equivalent in Euros) were not surveyed because it was believed that these banks would probably not be involved in making sizable commercial loans. Two hundred fiftyeight usable responses were obtained resulting in a 30.63 percent response rate. Table 1 presents descriptive information on the respondents.

Table 1

Description Of Respondent Groups

(assets in thousands of dollars)

\begin{tabular}{clccc} 
Group* & $\begin{array}{l}\text { Accounting } \\
\text { Tradition }\end{array}$ & $\begin{array}{c}\text { Number of } \\
\text { Respondents }\end{array}$ & $\begin{array}{c}\text { Mean of } \\
\text { Total Assets }\end{array}$ & $\begin{array}{c}\text { Mean Years } \\
\text { of Lending } \\
\text { Experience }\end{array}$ \\
\hline 1 & American & 42 & 450,974 & 13.60 \\
2 & American & 36 & 470,322 & 17.32 \\
3 & American & 37 & 455,760 & 16.73 \\
4 & American & 32 & 461,489 & 15.14 \\
1 & Germanic & 22 & 411,610 & 14.23 \\
2 & Germanic & 26 & 390,200 & 15.74 \\
3 & Germanic & 29 & 463,570 & 16.49 \\
4 & Germanic & 21 & 386,711 & 15.21 \\
\hline
\end{tabular}

* (1) cumulative method; to FIFO, (2) retrospective method; to FIFO, (3) cumulative method; to average cost, and (4) retrospective method; to average cost.

\section{RESPONSE ANALYSIS}

The focal point of this study is to determine if the method of recording changes in accounting principle, and/or the direction of the principle change and/or the accounting tradition has an affect on credit decisions made by bank loan officers. The principal model is a $2 \times 2 \times 2$ MANOVA. A MANOVA is appropriate to use in this case because multiple dependent variables exist, loan amount and interest. MANOVA analysis is able to test for 
differences between means when there are multiple independent variables as well as more than one dependent variable.

The results of the MANOVA are shown in Table 2. Based on a significance level of .05, only the interaction effect between the accounting tradition and the method used to record principle changes is significant. This indicates that loan decisions are different depending on the home country of the decision maker in conjunction with the method used to record the principle change. When the MANOVA test statistic produces a rejection of the null hypothesis for a main effect or an interaction, separate univariate ANOVA designs "may suggest which of the elements of the vector variable are contributing most to the discrimination of the groups, or alternately, which variables are most affected by the treatments" (Cooley and Lohnes, 1971, p. 230). The ANOVA tests for differences between group means using one dependent variable at a time. Therefore, a three-factor $(2 \times 2 \times 2)$ analysis of variance was performed for each response variable.

Table 2

\section{Overall MANOVA Results}

\begin{tabular}{lll} 
Effect & F-Value & Probability \\
\hline Accounting Tradition & 00.68 & 0.5081 \\
Accounting Method & 00.09 & 0.9100 \\
Direction of Change & 00.02 & 0.9839 \\
Tradition/Method Interaction & 18.10 & $<0.0001^{*}$ \\
Tradition/Direction Interaction & 00.02 & 0.9801 \\
Method/Direction Interaction & 00.70 & 0.1444 \\
Trad./Md./Dir. Interaction & 01.55 & 0.2141 \\
\hline
\end{tabular}

* Significant at the .05 level.

The results of the univariate test for the dependent variable of loan amount are presented in Table 3 . The ANOVA results indicate that the interaction effect between the accounting tradition and the method used to record principle changes is significant. However, the three-way interaction effect between the accounting tradition, method used and direction of the change is marginally significant. This indicates that the loan amount granted was affected by the accounting tradition of the decision maker in conjunction with the method of reporting accounting principle changes, and was also influenced to a lesser extent by the interaction between the accounting tradition of the user, the method of reporting principle changes and the direction of the principle change.

A Duncan's Multiple Range test was performed in order to determine the groups between which there are significant differences. The results reveal that significantly larger loan amounts were granted by U.S. decision makers to companies using the cumulative effect method of recording and reporting accounting principle changes. The largest loan amounts granted by U.S. users were to companies using the cumulative effect method with a change to FIFO inventory valuation, resulting in an increase to income. The decision makers from Germany and Austria under a Germanic tradition granted significantly larger loan amounts to companies using the retrospective method of reporting accounting principle changes. The largest loan amounts granted by the users were to companies using the retrospective method with a change to FIFO inventory valuation, resulting in an increase to reserves. The mean loan amount granted by participants in each group is presented in Table 4.

The results of the univariate test for the dependent variable of interest rate premium are presented in Table 5. No significant effect was found. Interest rates given by the respondents were not affected by the accounting tradition, the accounting method used, the direction of the change, or by the interaction between those variables. 
Table 3

Univariate ANOVA Results For The Response Variable Of Loan

\begin{tabular}{lll} 
Variable & F-Value & Probability \\
\hline Accounting Tradition & 00.19 & 0.6653 \\
Accounting Method & 00.49 & 0.4867 \\
Direction of Change & 00.05 & 0.8240 \\
Tradition/Method Interaction & 35.94 & $<0.0001^{*}$ \\
Tradition/Direction Interaction & 00.23 & 0.6354 \\
Method/Direction Interaction & 01.31 & 0.2533 \\
Trad./Md./Dir. Interaction & 03.02 & $0.0838^{* *}$ \\
\hline
\end{tabular}

* Significant at the .05 level. ** Marginally significant at the .10 level.

Table 4

Mean Loan Amounts Granted By Respondent Groups

(in thousands of dollars)

\begin{tabular}{llll} 
Tradition & Method & Direction & Loan Amount \\
\hline American & Cumulative & to Average Cost & $\$ 15,486$ \\
American & Retrospective & to FIFO & 13,519 \\
American & Cumulative & to FIFO & 17,286 \\
American & Retrospective & to Average Cost & 11,653 \\
Germanic & Cumulative & to Average Cost & 11,923 \\
Germanic & Retrospective & to FIFO & 17,023 \\
Germanic & Cumulative & to FIFO & 12,505 \\
Germanic & Retrospective & to Average Cost & 16,358
\end{tabular}

Note: A change to FIFO resulted in an increase in net income or stockholders' equity through retained earnings or reserves; a change to average cost resulted in a decrease in net income or stockholders' equity through retained earnings or reserves.

Table 5

Univariate ANOVA Results For The Response Variable Of Interest

\begin{tabular}{lll} 
Variable & F-Value & Probability \\
\hline Accounting Tradition & 1.27 & .2615 \\
Accounting Method & 0.00 & .9989 \\
Direction of Change & 0.05 & .8219 \\
Tradition/Method Interaction & 1.19 & .2764 \\
Tradition/Direction Interaction & 0.09 & .7695 \\
Method/Direction Interaction & 0.87 & .3530 \\
Trad./Md./Dir. Interaction & 0.32 & .5714 \\
\hline
\end{tabular}

\section{CONCLUSIONS}

According to IASB standards, companies must report changes in accounting principles using the retrospective restatement method, wherein reserves in stockholders' equity is adjusted for the cumulative effect of the change, net of tax. All statements presented for comparative purposes are restated with an adjustment to beginning reserves in stockholders' equity for the earliest year presented. In the U.S., GAAP has traditionally required the cumulative effect method for most principle changes. Using that method, the cumulative effect of the change, net of tax, flows through the income statement in the year of the change as a special item. This study sought to determine how the use of the cumulative-effect method versus the retrospective restatement method of recording principle changes would affect the decisions of bank loan officers from different accounting traditions; namely, American and Germanic. The results reveal that lending decisions are influenced by the interaction between the accounting tradition of the home country of the user in conjunction with the method used to record and report accounting principle changes. Higher loans were granted by U.S. users when the cumulative-effect method of recording principle changes 
was used, while higher loan amounts were granted by Germanic users when the retrospective restatement method of recording principle changes was used.

There could be multiple reasons for the results found in this study. The fact that higher loans were granted by U.S. bankers when using the cumulative-effect method, and by German and Austrian bankers when using the retrospective restatement method, regardless of if the effect resulted in an increase or decrease to net income or reserves, indicates that U.S. bankers may be accustomed to seeing principle changes reported using the cumulative effect method, while German and Austrian bankers may be accustomed to seeing principle changes reported using the retrospective restatement method. A penalty, in the form of a lower loan amount, was given when the principle change was reported using a method different than the individual bankers were accustomed to. The U.S. bankers may be fixated on seeing principle changes reported using the cumulative-effect method, while the German and Austrian bankers may be fixated on seeing principle changes reported using the retrospective restatement method, and may penalize companies who do not do so. Accounting research on functional fixation has provided evidence of such conditional responses. Abdell-khalik and Keller (1979) found that "some informed persons are unable to adopt readily new information or changes in measurement rules relating to some variables which they have consistently relied upon in making similar decisions in the past." Other studies have found that decision makers often continue to reflect elements of past behavior when they should be forgotten (Ashton, 1976; Chang and Birnberg, 1977; Dopuch and Ronen, 1973; Dyckman, Hoskin, and Swieringa, 1982).

The direction of change variable in this study did not have a significant effect, reflecting that even when the cumulative effect of a principle change flows through the income statement, bankers look to income from continuing operations and before special items when making decisions. When retrospective restatement was used, regardless of if the result was an increase or decrease to stockholders' equity, the amount of the loan granted was not significantly different. This might also indicate that whether a change in accounting principle flows through the income statement as a special item or is adjusted directly to stockholders' equity, may have no effect on U.S. statement users in the future once they become accustomed to seeing changes reported using the retrospective restatement method.

In May 2005, the FASB issued SFAS No. 154, Accounting Changes and Error Corrections. In the Statement, the FASB converges with IASB standards regarding principle changes. The Statement requires retrospective application of accounting principle changes, unless impracticable, effective beginning in fiscal year 2006. The standard, therefore, requires that the cumulative effect of a principle change be adjusted to retained earnings, with restatement of all prior period statements presented for comparative purposes. The international harmonization of accounting standards is a difficult goal to achieve. However, the FASB is taking steps in the right direction. This study indicates that it is important for the FASB as well as the accounting profession to attempt to educate statement users when U.S. standards change. Statement users may temporarily penalize companies when new standards are issued, for reporting in a way they are not accustomed to seeing. After the new standard takes effect, bankers will eventually become accustomed to seeing accounting principles changes reported retrospectively. Once that occurs, the method of recording principle changes should no longer effect lending decisions.

\section{REFERENCES}

1. Accounting Principle Board. 1971. APB No. 20: Accounting Changes. New York: AICPA.

2. Abdel-Khalik, A. R. and T. F. Keller. 1979. Earnings or cash flows: an experiment on functional fixation and the valuation of the firm. In Studies in Accounting Research No. 16. Sarasota, FL.: AAA.

3. American Institute of Certified Public Accountants. 1994. A Model of Business Reporting. New York: AICPA.

4. Ashton, R. H. 1976. Cognitive changes induced by accounting changes: experimental Evidence on the functional fixation hypothesis. Journal of Accounting Research (Supplement): 1-17.

5. Bouwman, M. J., P. Frishkoff, and P. A. Frishkoff. 1995. The relevance of GAAP-based information: a case study exploring some uses and limitations. Accounting Horizons 9 (December): 22-47.

6. Chandra, G. 1974. A study of the consequences on disclosure among public accountants and security analysts. The Accounting Review (October): 733-742. 
7. Chang, D. L. and J. G. Birnberg. 1977. Functional fixity in accounting research: perspective and new data. Journal of Accounting Research (Autumn): 300-312.

8. Chang, L. S., K. S. Most, and C. W. Brain. 1983. The utility of annual reports: an international study. Journal of International Business Studies (Spring/Summer): 63-84.

9. Cooley, W. W. and P. R. Lohnes. 1971. Multivariate Data Analysis. New York: John Wiley.

10. Danos, P., D. L. Holt, and E. A. Imhoff, Jr. 1989. The use of accounting information in bank lending decisions. Accounting, Organizations, and Society 14, No. 3: 235-246.

11. Dopuch, N. and J. Ronen. 1973. The effect of alternative inventory valuation methods-an experimental study. Journal of Accounting Research (Autumn): 191-211.

12. Dyckman, T. R., R. E. Hoskin, and R. J. Swieringa. 1982. An accounting change and information processing changes. Accounting, Organizations, and Society No. 1: 1-11.

13. Fairfield, P. M., R. J. Sweeney, and T. L. Yohn. 1996. Accounting classification and the predictive content of earnings. The Accounting Review 71 (July): 337-355.

14. Financial Accounting Standards Board. 2005. SFAS No. 154: accounting changes and error corrections. Norwalk, CT.: FASB.

15. - 2004. SFAS No. 153: exchange of nonmonetary assets. Norwalk, CT.: FASB.

16. 2004. SFAS No. 151: inventory costs. Norwalk, CT.: FASB.

17. Finger, C. 1994. The ability of earnings to predict future earnings and cash flow. Journal of Accounting Research 32 (Autumn): 210-223.

18. Gonedes, N. 1975. Risk, information, and the effects of special accounting items on capital market equilibrium. Journal of Accounting Research 13 (Autumn): 220-256.

19. Harper, R. M., W. G. Mister, and J. R. Strawser. 1987. The impact of new pension disclosure rules on perceptions of debt. Journal of Accounting Research (Autumn): 317-330.

20. Harper, R. M., W. G. Mister, and J. R. Strawser. 1991. The effect of recognition versus disclosure of unfounded postretirement benefits on lenders' perceptions of debt. Accounting Horizons (September): 50-56.

21. International Accounting Standards Board. 2003. Changes in accounting policies, errors, and estimates. London: IASB.

22. Nichols, L. M. 1997. An investigation of the effect of reporting changes proposed by the AICPA on lending decisions. Journal of Applied Business Research 13, No. 2 (Spring): 47-54.

23. Nichols, L. M. 1999. An investigation of the effect of comprehensive income reporting on lending decisions. Central Business Review XVIII, no. 1 (Winter): 17-21,

24. Porcano, T. M. 1981. A comparison of information needs and sources of the investment community. Akron Business and Economic Review (Fall): 43-52.

25. Strong, N. and M. Walker. 1993. The explanatory power of earnings for stock returns. The Accounting Review 68 (April) 385-399. 


\section{NOTES}

